\section{Suicide in teenagers during the COVID-19 pandemic in Cuba: actions for its prevention}

\author{
Claudia Elvira Casamayor Leiza', Julio César Pérez Yero², \\ Maydell Pérez Inerárity ${ }^{3 *}$ and Brayan Chávez Miguel ${ }^{4}$ \\ ${ }^{1}$ Teaching Polyclinic "XXX Anniversary”, Remedios, Villa Clara, Cuba \\ ${ }^{2}$ General Teaching Hospital of Remedios, Villa Clara, Cuba \\ ${ }^{3}$ Central University "Marta Abreu" of Las Villas, Villa Clara, Cuba \\ ${ }^{4}$ University of Medical Sciences, Villa Clara, Cuba
}

\section{Abstract}

Introduction: Suicidal behavior in teenagers constitutes a health problem that, given the necessary measures of social isolation taken by the global emergency of the COVID-19 pandemic, must generate timely actions for its prevention and control from the public health services.

Objective: To propose an action plan for the prevention of suicide in teenagers of the Remedios municipality, subjected to voluntary home confinement during the COVID-19 pandemic.

Methods: an observational, descriptive, cross-sectional study was carried out in the "XXX Anniversary" Teaching Community Polyclinic of the municipality Remedios. We worked with the population of 25 teenagers between 12 and 19 years old who made suicide attempts in the period 2019-2021. The empirical methods used were: bibliographic and documentary review, participant observation, focus group, semi-structured interview and questionnaire.

Results: The suicide attempt was common in female teenagers aged 17 to 19 years not identified as risk, the lack of motivation due to the study activity and the previous suicide attempts by ingesting psychotropic drugs without serious intention of dying predominated. The most frequent psychological disorders were emotional disorders, stress, depression, irritability, apathy and insomnia. Actions are presented for the prevention of suicide and promote behaviors that contribute to mental health in the context of COVID-19.

Conclusion: The prevention of suicidal behavior in teenagers in conditions of social isolation due to COVID-19, must include actions that facilitate the coping with stress, intra-family communication and resilience.

\author{
More Information \\ *Address for Correspondence: \\ Maydell Pérez Inerárity, Full Profesor, Department \\ of Psychology, Central University of Las Villas, \\ Villa Clara, Cuba, Tel: 42-281363; \\ Email: maydell@uclv.cu; maydell756@gmail.com \\ Submitted: April 26, 2021 \\ Approved: May 06, 2021 \\ Published: May 07, 2021
}

How to cite this article: Leiza CEC, Yero JCP Inerárity MP, Miguel BC. Suicide in teenagers during the COVID-19 pandemic in Cuba: actions for its prevention. J Community Med Health Solut. 2021; 1: 001-006.

DOI: 10.29328/journal.jcmhs. 1001007 1ORCiD: orcid.org/0000-0002-6119-713x 2ORCiD:orcid.org/0000-0002-6887-0411 ${ }^{3}$ ORCiD:orcid.org/0000-0002-5581-2263 ${ }^{4}$ ORCiD:orcid.org/0000-0001-8202-9859

Copyright: @ 2021 Leiza CEC, et al. This is an open access article distributed under the Creative Commons Attribution License, which permits unrestricted use, distribution, and reproduction in any medium, provided the original work is properly cited.

Keywords: Prevention; Suicide; Teenagers; COVID-19

Check for updates

OPEN ACCESS

\section{Introduction}

Suicide is a social and health problem that affects young people and teenagers, becoming the leading cause of external death, doubling mortality from traffic accidents in that age group as reported by Castellvi, P \& Piqueras JA. [1].

In the studies by Ceballos, et al. [2] found that suicide moves through a process of different nature and severity, ranging from ideation (idea of death as rest, death wishes and suicidal ideation) to increasing behavioral gradation (threats, gestures, attempts and completed suicide). On the other hand, Siabato, Forero and Salamanca, [3] affirmed that suicide is an expression of the lack of adaptive mechanisms of the subject to their environment, the result of a current or permanent conflictive situation that generates a state of emotional tension, or a consequence of the imbalance of your inner psychology.

The COVID-19 pandemic has had physical, psychological, social, economic and health consequences worldwide, said the researchers Ribot, Chang and González, [4]. In the absence of a definitive cure, the increase in the number of infections globally and the unavoidable implementation of social isolation measures as a way to reduce the risk of disease transmission, this situation currently constitutes, a challenge for healthcare professionals health in all fields. 
As a measure to prevent its spread, in Cuba, voluntary home confinement has predominated, and to a lesser extent mandatory quarantine has been ordered, which has impacted on living conditions, which have become threatening to wellbeing and health.

Teenagers have been subjected to separation from friends, the breaking of the daily routine and adaptation to an unknown and imposed routine, uncertainty about the appropriate behavior in the face of the possibility of death, all of which become stressors. But national health systems must focus on the relevance of addressing the problem with a positive approach, on the potentialities that must be stimulated in individuals so that they can exercise better control over their own lives, so that the perception of risk and health protective factors such as self-efficacy, resilience, optimism.

The Cuban Ministry of Public Health created the Suicidal Behavior Prevention Program in 1989. According to Hernández \& Villarreal, [5], among its objectives are the establishment of the surveillance system and the conduct of investigations to classify suicidal behavior, reduce morbidity due to suicide attempt and mortality due to suicide, paying special attention to avoiding the first attempt, the repetition of the act and the fatal outcome of the same. However, the National Directorate of Medical Records and Health Statistics reported in its Anuario Estadístico de Salud, 2019 (Statistical Yearbook of Health, 2019) [6], that the death rate from suicide at the end of 2019 was 13 per 100,000 inhabitants, occupying the third cause of death from 10 to 19 years with 26 deaths and a rate of 2.1 per 100,000 inhabitants of these ages, which exceeded the year 2018 with a rate of 1.7 per 100,000 inhabitants.

In a report from the Department of Health Surveillance (2019) it was reported that in the province of Villa Clara at the end of 2019, suicide was the ninth cause of death and the fifth in years of life potentially lost, with an adjusted rate of 9,7 deaths per 100,000 inhabitants, the third highest in the country. The 15-49 age groups were the one with the highest contribution. Suicide was the leading cause in years of life lost per deceased, for each of those who stopped living for approximately 19.7 years; this being one of the causes that most contributes to early mortality. The municipality of Remedios, with 8 deaths by suicide and a rate of 20.4 per 100,000 inhabitants, was among those that exceeded the provincial average. In the following year, there were 32 suicide attempts and of these 16 in the health area of the "XXX Anniversary" polyclinic, of which $37.5 \%$ occurred in children under 19 years of age.

According to the studies by Pérez [7], the health professional, "due to his close relationship with the community, is in a better position to detect the alleged suicide and knowing the particularities of this anomalous behavior, to exercise the actions of health that prevent this act".

Considering the high incidence of suicide attempts in teenagers in the Remedios municipality and the recognized need to strengthen the health system through the design and implementation of interventions that mitigate the negative effects of COVID-19 on mental health, it was decided carry out an investigation whose general objective was to propose an action plan for the prevention of suicidal behavior of teenagers subjected to voluntary home confinement during the COVID-19 pandemic. It is intended that the action plan becomes a tool for preventive work with this vulnerable group in the context of Primary Health Care.

\section{Methods}

A cross-sectional descriptive observational study was carried out at the "XXX Anniversary" Community Teaching Polyclinic, of the Remedios municipality in the period between January 2019 and December 2020. The risk factors and triggering situations of the suicide attempt were identified in teenagers through the collection and qualitative interpretation of data, to deepen the subjective perspective of teenagers, their expectations, experiences, interests, motivations and it was complemented with the information contained in the medical records from which all the information of the interrogation was collected to the patient, the antecedents and aspects related to the suicidal behavior. An action plan for its prevention was proposed, which was positively valued by specialists.

The techniques used were: semi-structured interview, participant observation, documentary review and questionnaire for the evaluation by specialists of the proposal. The data obtained were stored in an automated data file provided by the statistical package "Statistical Package for Social Sciences" (SPSS) version 20.0 for Windows. In the inferential statistics, the Homogeneity Test (Chi Square) was used, a level of significance was set $(\alpha=0.05)$. The statistical decision was made taking into account the significance $(p)$ of the statistician. When $p<\alpha$, a significant difference was considered between the mean values compared. Absolute and relative frequency distributions were made.

The population was made up of a total of 25 teenagers, aged 12 to 19 years, who made suicide attempts in the period from January 2019 to December 2020, who resided in the municipality of Remedios at the time of the study. Nonprobabilistic sampling by criteria was carried out. As no case was excluded from the population, we worked with its entirety.

\section{Inclusion criteria:}

- Adolescent between the ages of 12 and 19, who makes a suicide attempt during the investigation.

- Residence in the municipality of Remedios.

- Attended in the Mental Health Center of the municipality.

- Voluntary consent for adolescent participation. 
Exclusion criteria: Manifest desire of not wanting to participate in the study, physical or mental disability.

Ethical considerations: The principles of ethics in scientific research related to respect and autonomy, justice and beneficence were complied with. The study was approved by the ethics committee of the Polyclinic "XXX Anniversary" of Remedios.

\section{Results}

The research included a total of 25 teenagers who made a suicide attempt in the health area of the "XXX Anniversary" polyclinic of the Remedios municipality during the 2019-2020 periods; table 1 shows the distribution by age and sex. The risk of suicide attempt increased with age, 3 were reported between 12 and 14 years that constituted $12 \%$, with ages between 14 and 16 years there were 9 suicide attempts that constituted $36 \%$ and between 17 and 19 years 13 for $52 \%$.

$\mathrm{X} 2=0.8547 p=0.6522$ Ratio: Female/male 4: 1

The highest frequency occurred in the female sex, which constituted $80 \%$ of the cases. From the statistical point of view, the presence of a significant association between age and sex was not determined, $p=0.6522$, since the female sex was predominant in all age groups.

Graph 1 shows that according to occupation, students predominated in a number of $19(76 \%)$, this is consistent with the Cuban educational policy that establishes compulsory education for people in middle and early adolescence.

Table 2 lists the risk factors prior to the suicide attempt. Most of the teenagers were dispensed as suicidal risk in their health area, which reveals the work carried out by the basic work group that attends the program for the care of this vulnerable group. Another fact to highlight is the prior communication of the suicidal idea. This is a factor that alerts representatives of public health and the family to preventive work.

Table 1: Distribution of the sample, according to age and sex.

\begin{tabular}{|c|c|c|c|c|c|c|}
\hline \multirow{2}{*}{ Age (Years) } & \multicolumn{3}{|c}{ Male } & \multicolumn{2}{c|}{ Female } & \multicolumn{2}{c|}{ Total } \\
\cline { 2 - 7 } & $\#$ & $\%$ & $\#$ & $\%$ & $\#$ & $\%$ \\
\hline $12-14$ & 0 & 0,0 & 3 & 12,0 & 3 & 12,0 \\
\hline $14-16$ & 2 & 8,0 & 7 & 28,0 & 9 & 36,0 \\
\hline $17-19$ & 3 & 12,0 & 10 & 40,0 & 13 & 52,0 \\
\hline Total & 5 & 20,0 & 20 & 80,0 & 25 & 100 \\
\hline
\end{tabular}

Source: Clinical history.

Table 2: Risk factors prior to suicide attempt in teenagers. Risk factors preview to the suicide attempt

\begin{tabular}{|c|c|c|}
\hline Be registered as a suicide risk & 10 & 40,0 \\
\hline Suicidal idea communication & 4 & 16,0 \\
\hline Previous suicide attempt & 3 & 12,0 \\
\hline Previous psychiatric treatment & 1 & 4,0 \\
\hline Total & 18 & 72,0 \\
\hline
\end{tabular}

Source: Clinical history.

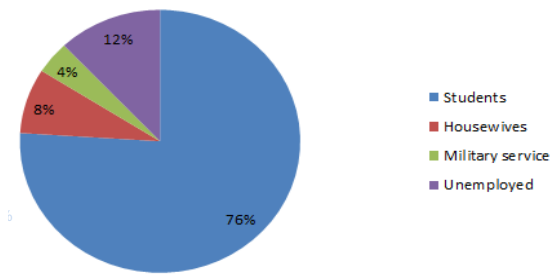

Graph 1: Distribution according to occupation of teenagers with suicide attempt.

The possible situation or conflict that triggered suicidal behavior in teenagers (Table 3) shows that the most frequent were conflicts at home in 17 cases, representing 68\%, partner conflicts in 9 teenagers for $36 \%$, and home confinement, 8 teenagers $(32 \%)$.

Other reasons were the death of a family member (8.0\%), as well as imitation behavior and maladjustment to general military service.

Table 4 shows the methods used by teenagers in the suicide attempt. The ingestion of psychotropic drugs predominated in 15 , which constituted $60 \%$ of the total under study, and in second place the ingestion of other drugs in 8 teenagers for $32 \%$.

Other forms used were incomplete hanging or vessel section: Performed by 1 adolescent in each case respectively $(4 \%)$.

The ingestion of psychotropic drugs was the method most used by women and men with $60 \%$ in both, in the former the ingestion of other drugs was also frequent (35\%). Incomplete

\begin{tabular}{|c|c|c|}
\hline Table 3: Possible situation or conflict that stimulated suicidal behavior in teenagers. \\
\hline Conflict situations & $\#$ & $\%$ \\
\hline Conflicts at home & 17 & 68,0 \\
\hline Couple conflicts & 9 & 36,0 \\
\hline Home detention for COVID-19 & 8 & 32,0 \\
\hline Death of a relative & 3 & 12,0 \\
\hline Imitation & 2 & 8,0 \\
\hline Maladjustment to general military service & 2 & 8,0 \\
\hline Source: Clinical history. & & \\
\hline
\end{tabular}

Source: Clinical history.

Table 4: Methods used by teenagers, according to sex, for the suicide attempt.

\begin{tabular}{|c|c|c|c|c|c|c|c|}
\hline \multirow{2}{*}{ Method used } & \multicolumn{9}{c|}{ Sex } \\
\cline { 2 - 7 } & \multicolumn{2}{|c|}{ Male (5) } & Female (20) & \multicolumn{2}{|c|}{ Total (25) } \\
\cline { 2 - 7 } & $\#$ & $\%$ & $\#$ & $\%$ & $\#$ & $\%$ \\
\hline Use of psychotropic drugs & 3 & 60,0 & 12 & 60,0 & 15 & 60,0 \\
\hline Use of other drugs & 1 & 20,0 & 7 & 35,0 & 8 & 32,0 \\
\hline Incomplete hanging & 1 & 20,0 & 0 & 0,0 & 1 & 4,0 \\
\hline Blood vessel section & 0 & 0,0 & 1 & 5,0 & 1 & 4,0 \\
\hline Total & 5 & 100 & 20 & 100 & 25 & 100 \\
\hline Source: Clinical history & & & & & & \\
\hline
\end{tabular}

Table 5: Seriousness of suicidal intention in teenagers.

\begin{tabular}{|c|c|c|}
\hline Seriousness of the suicide attempt & $\#$ & $\%$ \\
\hline Not serious & 8 & 32 \\
\hline Bit serious & 10 & 40 \\
\hline Serious & 6 & 24 \\
\hline Very serious & 1 & 4 \\
\hline Total & 25 & 100 \\
\hline
\end{tabular}


Table 6: Action plan for the prevention of suicide in teenagers of the municipality Remedios.

\begin{tabular}{|c|c|c|c|}
\hline Actions & Methods & Techniques & Verifiable indicators \\
\hline \multicolumn{4}{|c|}{ Training procedures } \\
\hline $\begin{array}{l}\text { Professional improvement courses. } \\
\text { Elective course (subject) for careers in } \\
\text { medicine and psychology } \\
\text { Postgraduate courses }\end{array}$ & $\begin{array}{l}\text { Workshops } \\
\text { Course } \\
\text { Training }\end{array}$ & $\begin{array}{l}\text { Participatory diagnosis } \\
\text { Interviews } \\
\text { Questionnaire } \\
\text { Group discussions. } \\
\text { Problem Tree. } \\
\text { Participatory techniques }\end{array}$ & $\begin{array}{r}\text { Participation certificates } \\
\text { Subject programs }\end{array}$ \\
\hline \multicolumn{4}{|c|}{ Service procedures } \\
\hline Social comunication & $\begin{array}{l}\text { Face to face. } \\
\text { Transmission in groups through health hearings } \\
\text { Social communication events with themes of } \\
\text { adolescence and confrontation with conflicts } \\
\text { Work with community organizations. }\end{array}$ & $\begin{array}{l}\text { Interviews, questionnaire, group } \\
\text { discussions. } \\
\text { TV, radio }\end{array}$ & $\begin{array}{c}\text { Percentage of audiences made and } \\
\text { with quality } \\
\text { Number of people trained }\end{array}$ \\
\hline $\begin{array}{l}\text { Research for the early identification of the } \\
\text { risks of suicidal behavior, with the help of } \\
\text { representatives of the FMC and CDR }\end{array}$ & $\begin{array}{c}\text { Visits to adolescent homes } \\
\text { Interviews with key informants. } \\
\text { Work in community organizations }\end{array}$ & $\begin{array}{l}\text { Interviews, questionnaire, group } \\
\text { discussions }\end{array}$ & $\begin{array}{l}\text { Quantity and quality of the actions } \\
\text { carried out }\end{array}$ \\
\hline \multirow{7}{*}{ Psycho-educational intervention } & $\begin{array}{l}\text { Psychotherapy (individual and group) } \\
\text { Orientation and counseling }\end{array}$ & $\begin{array}{c}\text { Brief, non-exploratory or suppressive } \\
\text { techniques } \\
\text { Techniques of moderate or } \\
\text { long duration (exploratory or } \\
\text { reconstructive). }\end{array}$ & $\begin{array}{l}\text { Case reports } \\
\text { Evidence of participation }\end{array}$ \\
\hline & $\begin{array}{l}\text { Promote new spaces for healthy recreation for } \\
\text { teenagers in the locality, using social networks. }\end{array}$ & $\begin{array}{l}\text { Educational games, educational } \\
\text { software }\end{array}$ & $\begin{array}{l}\text { Existence of educational games, } \\
\text { educational software }\end{array}$ \\
\hline & $\begin{array}{l}\text { Link teenagers at risk to the systematic practice } \\
\text { of physical activity from home }\end{array}$ & $\begin{array}{l}\text { - Individual orientation interview. } \\
\text { - Educational chat }\end{array}$ & Work journal \\
\hline & $\begin{array}{c}\text { Family Orientation Workshops on the } \\
\text { management of teenagers at risk of suicide } \\
\text { attempt }\end{array}$ & $\begin{array}{l}\text { Interviews, questionnaire, group } \\
\text { discussions }\end{array}$ & $\begin{array}{l}\text { Events carried out and with quality } \\
\text { Number of participating family } \\
\text { members }\end{array}$ \\
\hline & - $\quad$ Technology transfer. & $\begin{array}{cc}- & \text { Interviews } \\
- & \text { Questionnaire } \\
- & \text { Group discussions } \\
- & \text { Problem Tree. }\end{array}$ & $\begin{array}{cc}- & \text { Programs } \\
- & \text { Methodologies } \\
- & \text { Software }\end{array}$ \\
\hline & Thematic advice & $\begin{array}{c}\text { Diagnosis and planning of } \\
\text { participation } \\
\text { Participatory techniques. } \\
\text { Diagnosis and planning of } \\
\text { participation. }\end{array}$ & $\begin{array}{l}\text { Results reports } \\
\text { Evidence of group participation }\end{array}$ \\
\hline & Accompaniment of group processes. & $\begin{array}{c}\text { Events. } \\
\text { - Stakeholder analysis }\end{array}$ & Documents. \\
\hline \multicolumn{4}{|c|}{ Investigation procedures } \\
\hline $\begin{array}{l}\text { Participatory and cooperative Action } \\
\text { Research }\end{array}$ & $\begin{array}{c}\text { Events } \\
\text { Socio-cultural intervention }\end{array}$ & $\begin{array}{l}\text { Participatory techniques } \\
\text { Logical framework } \\
\text { Resource guides. } \\
\text { Inventories } \\
\text { Records } \\
\text { Observation. }\end{array}$ & $\begin{array}{cc}\text { - } & \text { Amount of research designed } \\
\text { and applied. } \\
\text { - } \quad \text { Report of problems solved } \\
\text { through investigations }\end{array}$ \\
\hline \multicolumn{4}{|c|}{ Control points } \\
\hline Actions & Responsible persons & Participants & Verifiable indicators \\
\hline $\begin{array}{c}\text { Analyze in the Boards of Directors of the } \\
\text { health area, the program indicators related } \\
\text { to Suicidal Behavior }\end{array}$ & $\begin{array}{c}\text { Municipal Coordinator of the Mental Health } \\
\text { Program }\end{array}$ & $\begin{array}{l}\text { Responsible persons of Medical } \\
\text { Assistance in each health area. }\end{array}$ & $\begin{array}{l}\text { Proceedings of the board } \\
\text { directors }\end{array}$ \\
\hline $\begin{array}{c}\text { Control visits and advice to each office in } \\
\text { a systematic way }\end{array}$ & $\begin{array}{l}\text { Head of the Basic Working Group of the } \\
\text { health area }\end{array}$ & Basic health equipment & Results report \\
\hline $\begin{array}{l}\text { Discussion of } 100 \% \text { of suicide attempts } \\
\text { and completed suicides in the first } 21 \text { days } \\
\text { of known Suicidal Behavior }\end{array}$ & $\begin{array}{l}\text { Municipal Coordinator of the Mental Health } \\
\text { Program }\end{array}$ & Basic health team & Case discussion report \\
\hline
\end{tabular}

hanging occurred in 1 male adolescent and vessel section in a female adolescent, which represents $20 \%$ in both cases. There was no significant dependence between the adolescent's sex and the method used, $p=0.2095$.

The classification of the attempts according to the seriousness of the suicidal intention (Table 5) shows that they were classified as not serious in 8 teenagers for $32 \%$, little serious in 10 cases for $40 \%$, serious in 6 teenagers for $24 \%$ and very serious in 1 adolescent for $4 \%$.
In $100 \%$ of the teenagers studied, the presence of emotional disorders, depression, stress, apathy, pessimism and insomnia were determined. These last two increased during the period of social isolation due to a pandemic.

\section{Discussion}

The information obtained in this study indicates that the timely identification of suicidal behavior in adolescence is a priority aspect in Primary Health Care, since there is currently a tendency to increase cases at younger ages, which coincides 
with the above in the Castellvi \& Piqueras JA Studios, Hernández \& Villarreal, [1,5]. This is related to the age with the highest frequency of suicide attempt in teenagers from Remedios and with similar results from other Cuban studies $[8,9]$ that report an increase in suicide attempt in groups between 14 and 19 years.

Similarly, when examining the samples according to sex, a predominance of the female sex has been observed in the group of teenagers with suicidal behavior, in both Cuban studies [8-10], as foreigners [11,12], unlike the consummate suicide that appears in males with a higher prevalence, since women tend to use less lethal methods.

According to the results of current studies [13], when considering the most frequent emotional disorders in teenagers in this study in the isolation conditions imposed by COVID-19, they should be stimulated personal resources such as optimism and resilience, which allow them to adopt and maintain healthy lifestyles and experience well-being.

Another relevant indicator was the presence of violence and difficulties in family education as possible triggering situations for suicidal behavior. In this regard, Serrano \& Olave, 2017 [14] found the significant relationship between suicidal phenomenon and communication with family members. This was associated with a lower prevalence of suicidal thoughts and attempts in teenagers.

Likewise, Colombian researchers $[15,16]$ call attention to the importance of detecting and managing affective disorders for the prevention of suicide in the age group studied.

Proposal of an action plan for the prevention of suicide in teenagers of the Remedios municipality.

Strategic objective: Reduce the incidence of suicide attempts by teenagers in the Remedios municipality.

Specific objectives:

1. Develop actions to control compliance with the Suicidal Behavior Control Program.

2. Develop actions with intersectoral collaboration for the prevention of suicidal behavior in teenagers.

\section{Acknowledgement}

This article is fully funded by $<<$ Policlínico XX Aniversario. Remedios >> with grant number: $<<42395201>>$.

\section{Authorship}

(1) CC: participated in the conceptualization; formal analysis; the methodology; managing resources and writing the original draft.

(2) JP: participated in the formal analysis; the methodology; resource management; the writing, revision and editing of the manuscript.
(3) MP: participated in the formal analysis; the methodology; resource management; the writing, revision and editing of the manuscript

(4) BCh: participated in the formal analysis, resource management; the writing, revision and editing of the manuscript.

\section{References}

1. Castellvi P, Piqueras JA. El suicidio en la adolescencia: un problema de salud pública que se puede y debe prevenir. Rev. Estudios de Juventud. 2018; 18: 45-59. http://www.injuve.es/sites/default/files/ adjuntos/2019/06/3.el_suicidio_en_la_adolescencia_un_problema_ de_salud_publica_que_se_puede_y_debe_prevenir.pdf

2. Ceballos GA, Suarez Y, Suescún J, Gamarra LM, González KE, et al Ideación suicida, depresión y autoestima en adolescentes escolares de Santa Marta. DUAZARY. 2015; 12: 15-22. https://www.redalyc.org/ pdf/5121/512156301003.pdf

3. Siabato EF, Forero IX, Salamanca Y. Asociación entre depresión e ideación suicida en un grupo de adolescentes colombianos. Pensam Psicol. 2017; 15: 51-61.

4. Ribot VC, Chang N, González AL. Efectos de la COVID-19 en la salud mental de la población. Rev Haban Cienc Méd. 2020; 19: e3307. http:// www.revhabanera.sld.cu/index.php/rhab/article/view/3307

5. Hernández PA, Villarreal RE. Algunas especificidades en torno a la conducta suicida. MEDISAN. 2015; 19: 1051-1058. http://scielo.sld.cu/ scielo.php?script=sci_arttext\&pid=S102930192015000800014\&lng=es

6. de Salud AE. Ministerio de Salud Pública. Dirección Nacional de Registros Médicos y Estadísticas de Salud. 2019; 3. https://temas.sld. cu/estadisticassalud/

7. Pérez S. El suicidio, comportamiento y prevención. Rev. Cubana Med Gen Integr. 2017; 15: 196-217. http://scielo.sld.cu/pdf/mgi/v15n2/ mgi13299.pdf

8. Cortés A, ValdésII JA, SuárezIII RM, Prado JLT, Echemendía B. Causas y factores asociados con el intento de suicidio en adolescentes en la Provincia Sancti Spíritus. Revista Cubana de Higiene y Epidemiología. 2010; 48: 15-23. http://scielo.sld.cu/pdf/hie/v48n1/hie03110.pdf

9. Arias I. Factores de riesgo del intento suicida en adolescentes del policlínico René Vallejo de Bayamo. Rev Electron Zoilo. 2015; 40: http://revzoilomarinello.sld.cu/index.php/zmv/article/view/97/html_14

10. González M. Comparación de la capacidad para planificar y verificar acciones en adolescentes con conductas suicidas y sus pares. Tesis de maestría. Recuperado de. 2013. https://dspace.uclv.edu.cu/ handle/123456789/3822

11. Carlos HR, Alfredo HSM. Comportamientos de riesgo de suicidio y calidad de vida, por género, en adolescentes mexicanos, estudiantes de preparatoria. Ciência \& Saúde Coletiva. 2015; 20 : 3437-3445.http://www.scielo.br/scielo.php?script=sci_arttext\&pid $=$ S1413-81232015001103437

12. Silva D, Vicente B, Arévalo E, Dapelo R, Soto C. Intento de suicidio y factores de riesgo en una muestra de adolescentes escolarizados de Chile. Psicop y Psicol Clín. 2017; 22: 33. http://revistas.uned.es/index. php/RPPC/article/view/16170

13. Broche $\mathrm{Y}$, Fernández E, Reyes DA. Consecuencias psicológicas de la cuarentena y el aislamiento social durante la pandemia de COVID-19. Revista Cubana de Salud Pública. 2020; 46: e2488. http://scielo.sld. $\mathrm{cu} / \mathrm{pdf} / \mathrm{rcsp} / \mathrm{v} 46 \mathrm{~s} 1 / 1561-3127-\mathrm{rcsp}-46-\mathrm{s} 1-\mathrm{e} 2488$.pdf

14. Serrano CP, Olave JA. Factores de riesgo asociados con la aparición de conductas suicidas en adolescentes. 2017; 20: 139-147. 
15. Cervantes W, Melo E. El suicidio en adolescentes. Un problema en crecimiento. Duazary. 2008; 5: 148-154. https://www.redalyc.org/ pdf/5121/512156328012.pdf

16. Córdova MA, Cubillas MJ, Román R. Es posible prevenir el suicidio? Evaluación de un programa de prevención en estudiantes de bachillerato. Pensam Psicol. 2011; 9: 21-32. https://www.redalyc.org/ pdf/801/80122596002.pdf
17. Cequier A, González JR. COVID-19. Las consecuencias sociales, sanitarias y cardiovasculares. Rev Esp Cardiol Supl. 2020; 20: 1.

18. Díaz F, Toro A. SARS-CoV-2/COVID-19: el virus, la enfermedad y la pandemia. Medicina \& Laboratorio. 2020; 24: 183-205.

19. Sectorial Municipal de Salud. Remedios, Villa Clara, 2020. Informe del Departamento de Vigilancia en Salud. Cuadro de Salud del año 2019. 